\title{
Inheritance of resistance to head bug (Eurystylus oldi) in grain sorghum (Sorghum bicolor)
}

\author{
S. E. Aladele ${ }^{1^{*}}$ and I. E. Ezeaku ${ }^{2}$ \\ ${ }^{1}$ National Centre for Genetic Resources and Biotechnology, P.M.B. 5382, Ibadan, Nigeria \\ ${ }^{2}$ International Crops Research Institute for the Semi-Arid Tropics, P.M.B. 3491, Kano, Nigeria
}

Accepted 18 June 2003

\begin{abstract}
The inheritance of resistance to head bug (Eurystylus oldi) was studied in ten populations of sorghum derived from crossing three susceptible sorghum elite varieties (ICSV 111, ICSV 112 and ICSV 400), and two resistant sorghum varieties (Malisor 84-7 and KSV 4). Parental lines, $F_{1}$ and $F_{2}$ populations were sown on a Randomized Complete Block Design in two replications. Artificial infestation of head bugs on sorghum was employed in carrying out the experiment. Samples of 5 panicles each from every artificially infested plot were observed. Resistance to head bug in sorghum seems to be controlled by a single pair of recessive genes in Malisor 84-7 x ICSV 400 and Malisor 84-7 x ICSV 111. The cross, KSV 4 x ICSV 112 appeared to be controlled by double recessive pair of genes. Head bug population affects quality of grains rather than the yield produced. There is a negative correlation (0.095 ) between head bug population and the germination percentage of the grain. Positive relationship exists between glume size and head bug population, which suggests that longer glumes harbour more head bug.
\end{abstract}

Key Words: Head bug (Eurystylus oldi), Infestation, Anthesis, Resistance, Susceptible, Inheritance.

\section{INTRODUCTION}

Sorghum head bug, Eurystylus oldi, occur in 60 to $100 \%$ of farmers' sorghum field, and affects both traditional and improved cultivars This is based on survey of head bug population carried out in sorghum growing area of Cameroon and Chad republic by Ajayi and Tabo as reported by (ICRISAT, 1996). Eurystylus $s p$ became important pest of grain sorghum in recent years with the introduction of early flowering cultivars with compact panicles. Yield losses of up to $86 \%$ have been attributed to head bug damage (ICRISAT, 1990). The head bug feed mainly on developing grains and occasionally on other tender parts of the plant. The nymph and adults suck sap from the developing grains, which remain unfilled, shrivelled, and in severe infestations become

*Corresponding author: E-mail: sundayaladele@yahoo.com completely chaffy (Sharma, 1985). Varieties with lax support lower population of head bug and suffer less grain damage than those with compact panicles (ICRISAT, 1995). It was reported by Tabo et al. (1999) that elite varieties, with semi-compact head are more susceptible to head bug than cultivars possessing panicles with open head.

The biology and population dynamics of head bug have been studied, but the seasonal activities of its attack on sorghum have not been adequately investigated (Ratnadass et al., 1995).

One female adult lays an average egg of 517 eggs, all of which are capable of hatching into a full-grown adult bug. The life cycle of head bug from egg to adult takes only about 12 days, several generations of this insect develop within a season, which contribute to a high population on a single field of sorghum.

In a survey carried out in 1993, 1994 and 1995, the number of adult and nymph found on one sorghum head was as high as 637 (Ajayi and Ajiboye, 1997). This 
Table 1. The mean head bug population, germination percentage, grain yield, damage rating and glume size of Parents, $F_{1}$ and $F_{2}$ progenies.

\begin{tabular}{|c|c|c|c|c|c|c|}
\hline Pedigree & $\begin{array}{c}\text { Total } \\
\text { Plant } \\
\text { Sample }\end{array}$ & $\begin{array}{l}\text { Mean Head } \\
\text { bug } \\
\text { population }\end{array}$ & $\begin{array}{c}\text { Germinatio } \\
\text { ( (\%) }\end{array}$ & $\begin{array}{c}\text { Average } \\
\text { grain yield } \\
\text { (g/panicle) }\end{array}$ & $\begin{array}{l}\text { Head bug } \\
\text { damage } \\
\text { rating }(1-9)\end{array}$ & $\begin{array}{c}\text { Glume } \\
\text { size } \\
\text { (mm) }\end{array}$ \\
\hline Malisor 84-7 & 20 & 88 & 54 & 55 & 3.57 & 3.75 \\
\hline ICSV 400 & 20 & 416 & 27 & 65 & 3.45 & 3.64 \\
\hline ICSV 111 & 20 & 344 & 40 & 89 & 2.10 & 4.70 \\
\hline ICSV 112 & 20 & 330 & 37 & 59 & 4.95 & 1.86 \\
\hline KSV 4 & 20 & 223 & 56 & 59 & 3.36 & 2.00 \\
\hline Malisor 84-7 x ICSV 400(F $\left.F_{1}\right)$ & 77 & 334 & 59 & 71 & 2.98 & 1.68 \\
\hline Malisor 84-7 x ICSV 400(F $\left.F_{2}\right)$ & 582 & 240 & 74 & 62 & 4.35 & 3.00 \\
\hline Malisor 84-7 x ICSV $111\left(\mathrm{~F}_{2}\right)$ & 497 & 188 & 68 & 72 & 2.55 & 1.50 \\
\hline $\mathrm{KSV} 4 \mathrm{x} \operatorname{ICSV} 112\left(\mathrm{~F}_{1}\right)$ & 79 & 457 & 55 & 79 & 2.55 & 2.81 \\
\hline KSV 4 x ICSV $112\left(F_{2}\right)$ & 700 & 291 & 48 & 69 & 3.40 & 2.60 \\
\hline
\end{tabular}

population can make the sorghum grains totally worthless at harvest because the grain development could have been distorted, become shrivelled and may not germinate if sown. Moreover, the nutritive value of the grain becomes reduced, and the malting quality is adversely affected due to poor germination.

The knowledge of the mode and nature of resistance to this insect pest will enhance the possibility of incorporating the genes for resistance into the susceptible but high yielding varieties. Chemical control is expensive and hazardous to the environment; therefore the best option for total control is to develop genetically resistant cultivars. Our objective therefore is to establish the mode of inheritance of genes controlling resistance to head bug in grain sorghum.

\section{MATERIALS AND METHODS}

Crosses were made at Dadin Kowa (Gombe state, Nigeria) during off-season of 1995 between head bug resistant varieties (Malisor 84-7 and KSV 4), and high yielding but susceptible sorghum varieties; ICSV 111, ICSV 112 and ICSV 400.

During the rainy season of 1996 crosses generated were evaluated in Bagauda on a plot of 2 rows of $5 \mathrm{~m}$ long. $F_{2}$ progenies were obtained by bagging all $F_{1}$ plants. Each true panicle was harvested and threshed separately. Five hundred and eighty-two $F_{2}$ progeny seeds were generated in a cross between Malisor 84-7 and ICSV 400 while $700 \mathrm{~F}_{2}$ and $497 \mathrm{~F}_{2}$ were produced in a cross between KSV 4 x ICSV112 and Malisor 84-7 x ICSV 111 respectively. Each progeny were planted in a plot of 2 rows of $5 \mathrm{~m}$ long on July 1997, at Bagauda Research farm located at $11^{\circ} 40^{\prime} \mathrm{N}$ and $8^{\circ} 30^{\prime} \mathrm{E}$ of Nigeria. The average long term annual rainfall is 600 $-1000 \mathrm{~mm}$. All the crosses with the five parents were sown in a randomised complete block design with two replications. Plant to plant spacing in a row was $25 \mathrm{~cm}$. Seedlings were thinned to one plant per stand. Fertilizer rate of $60 \mathrm{Kg} \mathrm{N}, 30 \mathrm{Kg} \mathrm{P}$ and $30 \mathrm{Kg} \mathrm{K}$ were basally applied, while $30 \mathrm{Kg} \mathrm{N}$ was top-dressed as urea 3 weeks after emergence. Two infester rows of Nagawhite were sown after every eight rows of test materials two weeks before the test entries for the experiments were sown. No insecticide was used except Apron plus used as seed dressing.

\section{Head bug artificial infestation}

Ten panicles in each row at half anthesis were tagged. Each of the five panicles was artificially infested with 20 pairs of adult males and females Eurystylus per panicle, using specially constructed cages. The remaining five panicles were used as control (that is, caged with no insects). At 20 days after infestation, the number of adults and nymphs in each panicle was counted. The sum for the five panicles for each plot was calculated.

Other traits observed includes visual score, glume size, grain weight, grain mass, percent floaters, germination percentage and egg count.

The head bug population was recorded for each plant observed. Each panicle was harvested, threshed and weighed separately. Each sample was also tested for germination to determine the effect of head bug damage on the viability of the grains.

Mean head bug population for parental lines, $F_{1}$ and $F_{2}$ progenies was calculated by adding all the head bug count for the population and dividing by the number of plant observed (Grewal et al., 1987). The mean head bug population for resistant parents is taken for dividing line for resistance in $F_{1}$ and $F_{2}$ progenies. Resistance for crosses involving Malisor $84-7$ is fixed at $1-88$ head bug population while susceptible is $>88$ head bug population. Crosses involving KSV4 was pegged at 223 for resistance while susceptible is head bug population $>223$. This is because Malisor 84-7 is early maturing while KSV4 matures late and stays longer on the field.

\section{RESULTS AND DISCUSSIONS}

Table 1 show that susceptible parents have very low germination percentage, an indication that head bug damage drastically reduces the viability of seeds. This 
Table 2. Correlation coefficient of five traits in ten sorghum populations.

\begin{tabular}{|c|c|c|c|c|c|}
\hline & $\begin{array}{l}\text { Head bug } \\
\text { population }\end{array}$ & $\begin{array}{c}\text { Germination } \\
\%\end{array}$ & $\begin{array}{l}\text { Grain yield } \\
\text { (g/panicle) }\end{array}$ & $\begin{array}{c}\text { Head bug } \\
\text { Damage rating } \\
(1-9) \\
\end{array}$ & $\begin{array}{c}\text { Glume } \\
\text { size }(\mathrm{mm})\end{array}$ \\
\hline Head bug population & 1.000 & & & & \\
\hline Germination \% & -0.497 & 1.000 & & & \\
\hline Grain yield (g/panicle) & 0.537 & -0.092 & 1.000 & & \\
\hline Head bug Damage rating (1-9) & -0.182 & -0.068 & -0.790 & 1.000 & \\
\hline Glume size $(\mathrm{mm})$ & 0.105 & -0.408 & 0.318 & 0.240 & 1.000 \\
\hline
\end{tabular}

Table 3. Genetic ratio for F2 population and estimates of chi-square for each cross.

\begin{tabular}{|l|c|c|c|c|c|}
\hline \multirow{2}{*}{ Cross } & \multicolumn{4}{|c|}{ Ratio in F2 Population } \\
\cline { 2 - 5 } & \multicolumn{2}{|c|}{ Observed } & \multicolumn{2}{c|}{ Expected (1:3 ratio) } & \multirow{2}{*}{$\chi^{\mathbf{2}}$} \\
\cline { 2 - 6 } & Resistant & Susceptible & Resistant & Susceptible & \\
\hline Malisor 84-7 x ICSV 400(F $\left.F_{2}\right)$ & 149 & 433 & 143 & 422 & 0.11 \\
Malisor 84-7 x ICSV 111(F $\left.F_{2}\right)$ & 170 & 327 & 124 & 372 & $22.48^{*}$ \\
KSV 4 x ICSV 112(F $\left.\mathrm{F}_{2}\right)$ & 329 & 371 & 175 & 525 & $180.69^{\text {ns }}$ \\
\hline
\end{tabular}

* -indicates significance at $P=0.05$

ns indicates non-significant at $P=0.05$

explains the negative correlation between head bug and germination percentage as shown in Table 2. There is no significant effect of the head bug population on grain yield. Table 1 shows that, ICSV 111 with 344 head bug produced the highest grain yield of $89 \mathrm{~g}$ per panicle against the 88 head bugs produced by Malisor 84-7, which had a yield of $55 \mathrm{~g}$ per panicle. The crosses between KSV4 x ICSV $112\left(F_{2}\right)$, although possess the highest head bug count of 457 produced $79 \mathrm{~g}$ per panicle. This suggests that head bug infestation affects quality of grain more than the quantity of grain produced.

There is a negative correlation between germination \% and grain yield (-0.092). This shows that the higher the germination \% the lower the grain yields and vice - versa. The possible reason is that the higher the grains produced per panicle, the greater the possibility of being attacked by many head bugs which invariably will distort the grains and rendered them less viable. The positive correlation ( 0.537 ) between the head bug population and the grain yield probably explain the above assertion. Head bug population is positively correlated to glume size, suggesting that the longer the glume the higher the population of the head bugs that the panicles will harbour, particularly when the glumes opens at the soft dough stage. Head bug population is negatively correlated to germination $\%$ and head bug damage rating, suggesting that the more the number of head bug on sorghum the poorer the grains become in appearance. Our findings confirm the report by Sharma (1985), which shows positive correlation between the number of head bugs and the quality of grain produced in sorghum.

Table 3 shows the genetic ratio and estimated of chisquare on the $F_{2}$ population. Observation on the mean head bug population suggests that head bug resistance is controlled by a pair of allelic genes (Gupta, 1995), and that susceptibility is dominant to resistance. This is evidently clear by the population of head bug on the F1 progenies, which is closer to the number recorded for the susceptible parents. The chi-square calculated for each cross shows that Malisor 84-7 x ICSV 400 and Malisor 84-7 x ICSV 111 conforms to the expected ratio of 3:1 for Susceptible versus Resistant. The $\mathrm{F}_{2}$ progenies of KSV 4 $x$ ICSV 112 do not conform to the single gene inheritance. When tested with 9:7 ratios, there seemed to be conformity with chi-square value of 2.52. This suggests that either KSV 4 is not resistant to head bug as previously claimed or its resistance is controlled by double recessive genes (Stansfield, 1969). It is observed 
that mean head bug population in $F_{2}$ is generally lower than in $F_{1}$ for all crosses. This observation suggests that crosses between resistant and susceptible varieties followed by guided selections over time could reduce head bug population to reasonable levels. This is an indication that there was inbreeding depression for head bug resistance in $F_{2}$ population. These findings are in agreement with those reported by Patil-kulkarni et al. (1972) and Rana et al. (1976). This study further confirms the resistance of Malisor 84-7 to head bug, while there is still doubt over the resistance of KSV 4 to head bug. Further investigation is therefore needed to prove the susceptibility or otherwise and the genetic factors controlling head bug resistance in KSV 4.

\section{REFERENCES}

Ajayi O, Ajiboye TO(1997). Non Crop plant host of the sorghum head bug (Eurystylus oldi) in West Africa. International Sorghum and Millet Newsletter 38:81-82.

Grewal RS, Lodhi GP, Paroda RS(1987). Inheritance of field resistance to Sorghum Oval leaf spot. Indian J. Genet. 47:41-44.

Gupta SC (1995). Allelic Relationships and Inheritance of Brown Midrib Trait in Sorghum. J. Hered. 86:72-74.
ICRISAT (International Crops Research Institute for the Seni-Arid Tropics)(1996). West African Programs Annual report. ICRISAT Sahelian Center, Niamey, Niger Republic.

ICRISAT 1995). .Annual report for 1994. Patancheru 502 324, Andhra Pradesh, India.

ICRISAT (1990). West African Programs Annual report. ICRISAT Sahelian Center, Niamey, Niger Republic.

Patil-Kulkarni BG, Puttarudrappa A, Kajjeri NB, Goud JV (1972). Breeding for rust resistance in Sorghum. Indian Phytopath. 25:166168.

Rana BS, Triphathi DP, Rao NGP (1976). Genetic Analysis of some exotic $x$ Indian crosses in Sorghum. XV. Inheritance of resistance t sorghum rust. Indian J. Genet. 36:244-249.

Ratnadass A, Doumbia YO, Ajayi O (1993). Bioecology of sorghum head bug and crop loss in West Africa. Pages 91-102 in Panicle insect pests of sorghum and pearl millet: Proceedings of an International Consultative Workshop on panicle insect pests of sorghum and pearl millet, 4-7 October 1993, ICRISAT Sahelian Center, Niamey, Niger Republic.

Sharma HC (1984). Screening for Host plant Resistance to Mirid Head Bugs in Sorghum. In Proceedings: International Sorghum Entomology Workshop, 15-21 July, 1984. Texas \& Management University, College station, Texas, USA.

Stansfield WD (1969). Theory and Problems of Genetics. Schaum's Outline Series. McGRAW-HILL Book company. New York. U.S.A.

Tabo R, Ogungbile AO, Gupta SC, Ajayi O (1999). Participatory Evaluation of Sorghum Cultivars in Northern Nigeria. International Sorghum and Millet Newsletter 40: 53-54. 